\title{
How important are forest elephants to the survival of woody plant species in Upper Guinean forests?
}

\author{
WILLIAM D. HAWTHORNE* and MARG P. E. PARREN† \\ *Department of Plant Sciences, Oxford University, South Parks Road, OX13RB, UK \\ $\dagger$ Department of Environmental Sciences, Wageningen University, P.O. Box 342, 6700 \\ AH Wageningen, The Netherlands \\ (Accepted 14th August 1999)
}

\begin{abstract}
Elephant populations have declined greatly in the rain forests of Upper Guinea (Africa, west of the Dahomey Gap). Elephants have a number of well-known influences on vegetation, both detrimental and beneficial to trees. They are dispersers of a large number of woody forest species, giving rise to concerns that without elephants the plant diversity of Upper Guinean forest plant communities will not be maintained. This prospect was examined with respect to four sources of inventory and research data from Ghana, covering nearly all (more than 2000) species of forest plant. Evidence supporting the hypothesis that plant populations are collapsing without elephants is conspicuously absent in these datasets, although Balanites wilsoniana is likely to suffer dramatically on a centennial scale in the absence of forest elephants. A few other species are likely to decline, although at an even slower rate. In the context of other processes current in these forests, loss of elephants is an insignificant concern for plant biodiversity. Elephant damage of forests can be very significant in Africa, but loss of this influence is more than compensated for by human disturbance. Elephants have played a significant part in the shaping of West African rain forest vegetation. However, it is the conservation of elephants that should be of primary concern. Tree populations should be managed to promote them, rather than vice versa.
\end{abstract}

KEY WORDS: elephant, Africa, forest, dispersal, regeneration, disturbance

\section{INTRODUGTION}

Humans have a profound influence on the distribution of elephants in Africa, often in subtle ways (Barnes et al. 1991). What repercussions will the local extinction of elephant populations have on the botanical composition of forests? Little is known about the forest elephant (Loxodonta africana cyclotis) in the Guineo-Congolian Region, relative to the extensive knowledge acquired about the savanna elephant (Loxodonta africana africana), and even this infraspecific 
taxonomy is not clear-cut (Buss 1961, 1990; Martin 1989; Wing \& Buss 1970). Savanna elephants are responsible (along with fire) for repeated damage to the tree populations of savannas (Barnes 1983, Lock 1975, Leuthold 1977, Smart et al. 1985, Spinage \& Guiness 1971).

Population densities of forest elephants have been estimated recently for many areas (e.g. Barnes et al. 1995, Dickinson 1990, Dudley et al. 1992; Merz 1986 a, b, c). Prins \& Reitsma (1989 - see also White 1994a) found that forest elephants make up the bulk of the mammalian biomass (52\% of the herbivores) in the rain forest of Gabon and suggest that forest elephants play a key role in African rain forest ecosystems. For West Africa, Martin (1989) estimated the total number of forest elephants in 1987 to be $c$. 3000. In contrast, the population of forest elephants in Central Africa was estimated to be 172400 in 1989 (Barnes et al., 1995). Populations can diminish quickly, however (Barnes et al. 1993).

Forest elephants must have once roamed over the entire closed forest zone of Ghana, but are presently restricted to five main areas (Figure 1) although the Enchi population is of uncertain status. Martin (1982) estimated the Bia population had around 200 individuals. According to densities presented by Dickinson (1990) the Goaso population should be of the same magnitude, while the Kakum population is estimated by Dudley et al. (1992) as 100-150 individuals. No density information is available for the Ankasa population, but their number might equal that of the Kakum population. So the total Ghanaian population can be estimated at 600-800 individuals, a small fraction of the levels suggested in historical records. There is much scope in Ghana to observe any broad effects of local elephant extinction, by comparing forest areas with and without them.

Elephants influence forests at two main levels: as opportunistic frugivores, by directly effecting the dispersal and regeneration of certain species; and by trampling, debarking and otherwise disturbing the forest (Hoft \& Hoft 1995; Johnstone 1967; Laws et al. 1970, 1975; Sheil 1996; Struhsaker et al. 1996; Wing \& Buss 1970). We will discuss the disturbance aspects in the conclusion, but the dispersal role needs more careful consideration. Our aim is to discuss the extent to which elephants are crucial to survival of Upper Guinean forest communities, with particular reference to plants. Upper Guinean forests are those from Ghana westwards, i.e. west of the Dahomey Gap (see White 1983).

Large birds and/or mammals are often the main seed dispersers of certain types of tree, particularly those with large fruits or seeds (Mack 1993, Roth 1987, Terborgh 1990). The larger dispersers are generally found to be more effective for late successional species, even for those that attract a wide range of potential dispersers, for the following reasons: (1) They tend to be more selective of large-seeded species. Late successional species tend to have larger seeds than pioneer ones, containing considerable food reserves, although there are obvious exceptions (e.g. Ricinodendron, a large-seeded pioneer, and Strombosia a relatively small-seeded non-pioneer tree); (2) they consume more fruits 


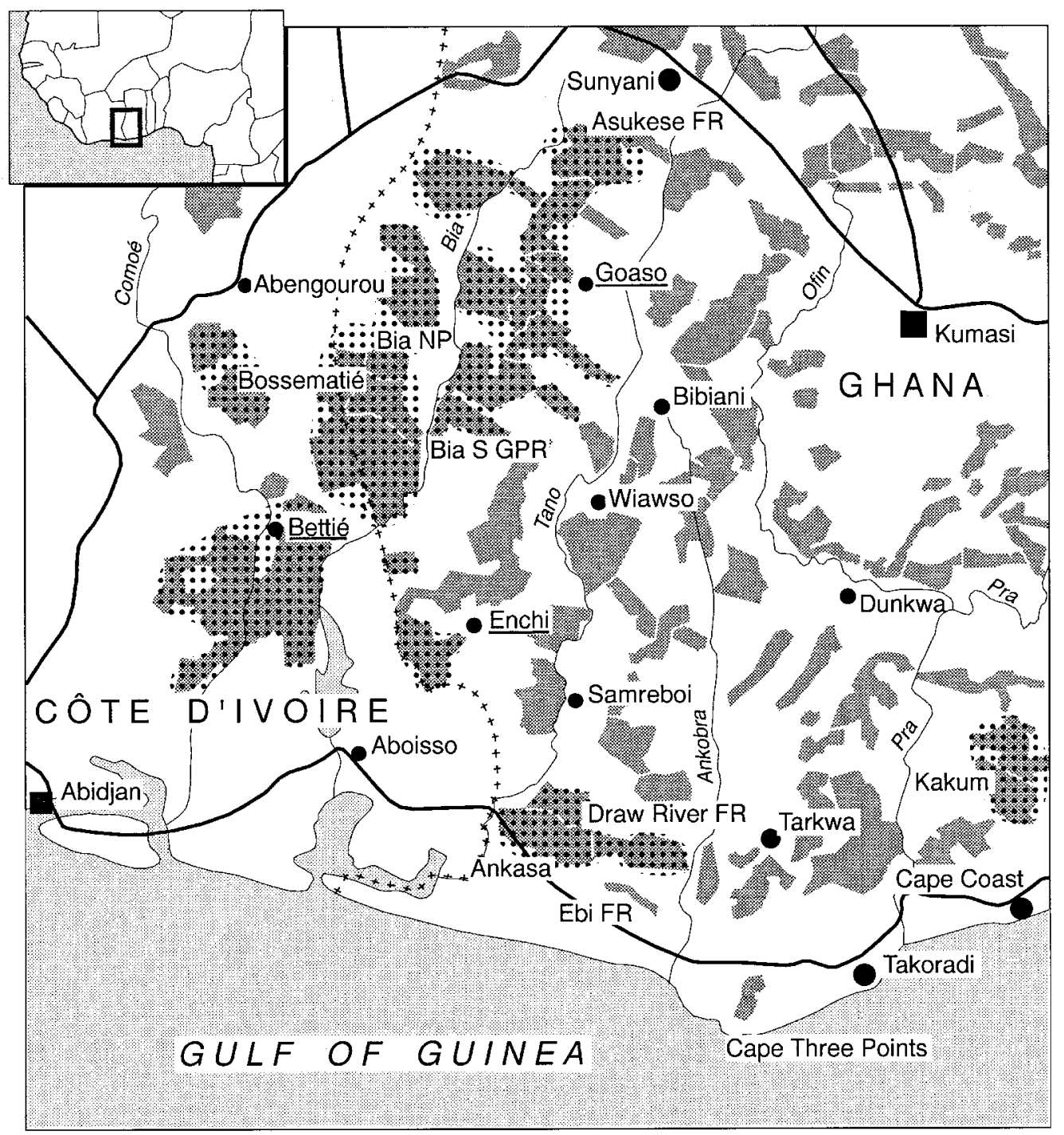

LEGEND:

\section{Forest under reservation}

\section{:::::: Ascertained forest elephant distribution area} ::::: (sightings 1988 till present )

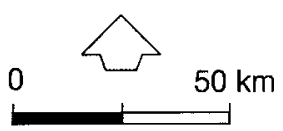

Figure 1. Present area of distribution of forest elephant populations (dotted) in Ghana and eastern Côte d'Ivoire. Major remnant forest blocks (forest reserves, national parks and game production reserves) are finely stippled. 
per feeding bout; and (3) they tend to carry seeds further before regurgitating or defecating them.

Efficient distribution might be especially important for those species which suffer heavy seedling mortality near their parents (Janzen 1970). Howe (1993) states that 'virtually wherever a quantitative test has been attempted, seeds or seedlings near large fruiting adults fare less well than members of a cohort a few tens of meters away', although there is direct evidence for such negative effects of adults for only a few species in Ghana (e.g. Turraeanthus africanus (Alexandre 1977)). In any case, a high seedling mortality near parents due at least to overcrowding and competition-and for some species due to trampling by large animals attracted to the mother trees when in fruit-is almost inevitable and trivial, and the potential benefits of elephant dispersal need to be examined on broader scales.

Fleshy or arillate fruits tend to be favoured and dispersed by animals. During the second half of the main dry season, the lean season for most animals, a peak in fruiting of animal-dispersed tree species occurs in the rain forest zone of West Africa (Alexandre 1980, De la Mensbruge 1966, Swaine \& Hall 1986, Taylor 1960). During this period forest elephants move from their preferred secondary vegetation, like chablis and deserted farmland (Barnes et al. 1991, Sachtler 1968), abandoned skidding trails (Merz 1986b) and logging sites, towards forest where fruiting trees of favoured species are to be found (e.g. Short 1981, White 1994b).

The role of the forest elephant as dispersal agent has been shown by Alexandre (1978) and Merz (1981) for Côte d'Ivoire; and Short (1983) and Lieberman et al. (1987) for Ghana. In Taï National Park, Côte d'Ivoire, Alexandre (1978) found that almost one third of 70 tree species studied were elephant-dispersed. The forest elephant eats up to $150 \mathrm{~kg}$ of plant material per day, of which a small proportion is seeds. Martin (1989) noted that seeds, or at least bits of fruit, occurred in 93\% of elephant droppings in Bia National Park. Since their digestion is superficial, $135 \mathrm{~kg}$ of droppings are deposited per forest elephant per day (Wing \& Buss 1970), at an average daily rate of defecation of 17 to 18 droppings (Merz 1986b, Wing \& Buss 1970). Forest elephants move an average of $c .500 \mathrm{~m} \mathrm{~h}^{-1}$ (Merz 1986c) and can wander many kilometres in a day.

Most studies have concluded that the forest elephant could play an essential role in the regeneration of certain tree species (e.g. Alexandre 1978, Merz 1986c, Short 1983, Waitkuwait 1992). Lieberman et al. (1987) substantiated this hypothesis with germination trials on fresh and ingested seeds of eight tree and one liana species eaten by forest elephants. Recently this has been repeated by Chapman et al. (1992) for the tree species Balanites wilsoniana. These authors also reported a beneficial effect on germination of the passage of the seeds through an elephant's gut.

Such research has led to the belief that several tree species would go extinct in the absence of forest elephants. In Côte d'Ivoire, Alexandre (1978) was 
surprised by the absence of saplings of Panda oleosa and Sacoglottis gabonensis in the Banco forest, and he suggested that the lack of regeneration was related to the absence of forest elephants for $c .100 \mathrm{y}$. Apparently, no other forest animal swallows Panda pyrenes, and elephants are known to relish Sacoglottis fruits which also have large, hard pyrenes. De Koning (1983: I, p. 65; recalling observations by Martineau in the 1930s) noted regeneration difficulties for Sacoglottis gabonensis and other species in the Banco and nearby forests and attributed this to the absence of big animals. Hall \& Swaine (1981) concluded a similar process for Tieghemella heckelii in Ghana: 'Seedlings occur in shade, but regeneration is rare-perhaps because of the lack of elephants'. Voorhoeve (1965) made the same link in Liberia: 'With the elephants being rapidly reduced in number and the high forest areas more and more limited, the distribution of Tieghemella will also be halted and the prospects of a natural regeneration are poor. Unless replanted by the Forest Service, the species will probably become extinct'. After extensive research work in Taï forest (Côte d'Ivoire) Alexandre (1978: p. 60) defined forest elephants as essential dispersers since: '... tant par le nombre d'espèces que par le nombre d'individues, la loxodontochorie est le mode de dissémination le plus fréquent des arbres de la strate dominante ... indispensable à la régénération des espèces'.

Although elephants obviously influence the regeneration and dispersal of some species, we now ask how significant is this likely to be on a national scale, and within the context of the forest community as a whole? Are there any signs of forest ecosystems 'falling apart' without elephants? Are there even any elephant-dispersed species whose regeneration is missing from areas where there are no elephants?

\section{METHODS}

Four data-sets were analysed, referred to as S1-S4, and these are summarized in Table 1. References to forest types or zones in Ghana follow Hall \& Swaine's (1981) terminology. Plant nomenclature follows Hawthorne (1990, 1995b).

Using the map-based botanical database FROGGIE (Forest Reserves of Ghana, Graphical Information Exhibitor; Hawthorne 1995a, Hawthorne \& Abu Juam 1995), we have scanned the distribution of all 2330 species in the sources of data mentioned in Table 1, and the size class distribution of all inventoried and identified tree species (c. 300, but some are grouped) in studies S2, S3 and S4, looking for evidence of an effect of local elephant extinction on plant species distribution or regeneration.

\section{RESULTS}

The vast majority of species in Ghana show no suggestion of being restricted to areas currently with (or without) elephants. For most trees, and non-trees with identifiable seedlings, there is no evidence of a lack of regeneration in 
Table 1. Sources of data on species distribution and regeneration in Ghana.

\begin{tabular}{|c|c|c|c|c|c|c|}
\hline Code & Inventory & Description and comment & Date & Species & Sizes & Reference \\
\hline $\mathrm{S} 1$ & $\begin{array}{l}\text { National tree } \\
\text { inventory: } \\
\text { Temporary } \\
\text { sample plots }\end{array}$ & $\begin{array}{l}1 \text { ha plots. Trees } \\
\geq 30 \mathrm{~cm} \text { dbh recorded } \\
\text { throughout, with subplots } \\
\text { of } 0.1 \text { ha for trees } \\
\geq 10 \mathrm{~cm} \text { dbh, and } \\
\text { subplots of } 0.05 \text { ha for } \\
\text { trees } \geq 5 \mathrm{~cm} \text { dbh. }\end{array}$ & 1986-1991 & All trees & $\begin{array}{l}\geq 5 \mathrm{~cm} \\
\mathrm{dbh}\end{array}$ & $\begin{array}{l}\text { Wong (1989), } \\
\text { Hawthorne \& } \\
\text { Abu Juam } \\
\text { (1995), } \\
\text { Hawthorne } \\
\text { (1995b) }\end{array}$ \\
\hline S2 & $\begin{array}{l}\text { Regeneration } \\
\text { studies }\end{array}$ & $\begin{array}{l}\text { Studies of tree } \\
\text { regeneration in fire- and } \\
\text { logging-damaged forest } \\
\text { both, coincidentally, in } \\
\text { elephant areas (Bia South } \\
\text { G.P.R. (Game Production } \\
\text { Reserve) and Asukese F.R. } \\
\text { (Forest Reserve). There } \\
\text { are, however, no equivalent } \\
\text { data from non-elephant } \\
\text { areas. }\end{array}$ & 1987 & $\begin{array}{l}\text { Trees, and } \\
\text { common } \\
\text { non-trees }\end{array}$ & All & $\begin{array}{l}\text { Hawthorne } \\
(1993,1994)\end{array}$ \\
\hline S3 & $\begin{array}{l}\text { Botanical } \\
\text { survey }\end{array}$ & $\begin{array}{l}\text { Crude abundance scores, } \\
\text { with canopy tree counts. } \\
\text { Two separate botanical } \\
\text { surveys, with different } \\
\text { aims but similar methods, } \\
\text { together establishing a } \\
\text { good picture of plant } \\
\text { distribution in Ghana }\end{array}$ & $\begin{array}{l}1976, \\
1990-1992\end{array}$ & $\begin{array}{l}\text { All vascular } \\
\text { plants }\end{array}$ & $\begin{array}{l}\text { No tree } \\
\text { sizes } \\
\text { were } \\
\text { recorded }\end{array}$ & $\begin{array}{l}\text { Hall \& } \\
\text { Swaine } \\
(1981), \\
\text { Hawthorne \& } \\
\text { Abu Juam } \\
(1995)\end{array}$ \\
\hline $\mathrm{S} 4$ & $\begin{array}{l}\text { Tree } \\
\text { regeneration } \\
\text { and elephant } \\
\text { distribution }\end{array}$ & $\begin{array}{l}\text { Four reserves } \\
\text { were studied: Bia } \\
\text { Tributaries South G.P.R. } \\
\text { \& Ankasa G.P.R. with } \\
\text { elephants; Tano Nimiri } \\
\text { F.R. (last elephant sighting } \\
\text { 1944) \& Bura F.R. (no } \\
\text { sightings since } c .1910 \text { ). }\end{array}$ & 1990 & $\begin{array}{l}41 \text { Selected } \\
\text { tree species }\end{array}$ & $\begin{array}{l}>1 \mathrm{~m} \\
\text { height }\end{array}$ & $\begin{array}{l}\text { Parren } \\
(1991)\end{array}$ \\
\hline
\end{tabular}

these areas. We have selected and summarize (in alphabetical family order) a short list of those species most likely to show a dependence on elephants, based on results and inferences of previous work.

Parinari excelsa Sabine (Chrysobalanaceae)

Short (1983) noted that the seasonal migrations of the elephants in Bia South G.P.R. were from Parinari excelsa-rich areas to Tieghemella-rich areas, in tune with the fruiting seasons of these species. Germinating seeds were found in elephant dung (Alexandre 1978). The fruit is a plum-like drupe which is also attractive to a variety of mammals, including humans (White 1976). This species regenerates well on old roads in elephant-rich Bia and Asukese forests (S2). It was found to be common in Upland and other Evergreen forests in Ghana and elsewhere, even in areas with no elephants. There are, however, rather more records in the Moist Semi-deciduous northwest subtype (where elephants occur), than in the moister Moist Semi-deciduous southeast subtype 
(no elephants), suggesting a beneficial effect of elephants or other animals (S3). In S1 this species was confused on occasions with other Ghrysobalanaceae, but results are in accordance with $\mathrm{S} 3$ where the species were distinguished accurately. In conclusion, this species appears to be promoted by elephants, but can thrive without them. The data for other Chrysobalanaceae, several of which have similar fruits (White 1976), similarly indicate no strong dependence on elephants.

Diospyros cooperi (Hutch. \& Dalz.) F. White (Ebenaceae)

This species has small yellow fleshy fruits of a type likely to be dispersed, if at all, by birds. (Diospyros spp. in general are often dispersed by primates in Gabon, although D. mannii is also dispersed by elephants there (Tutin et al. 1996).) However, D. cooperi has an interesting distribution. It is restricted sharply to the west of Ghana. It is common in the elephant areas of Bia South G.P.R. and Krokosua Hills F.R., and absent from many areas where elephants are missing, so a statistical test would probably indicate a loose association between the presence of these species. However D. cooperi is not known in Kakum and other elephant areas, and in view of the apparent unsuitability of its fruit for specific elephant dispersal it is likely to be restricted to the west of the country as a result of slow diffusion from a refuge area (Hall \& Swaine 1981, Hawthorne 1996), rather than because of lack of elephants elsewhere.

Ricinodendron heudelotii (Baill.) Pierre ex Pax (Euphorbiaceae)

This tree has a yellow, three-seeded drupe with 7-10 large seeds (Hall \& Swaine 1981), eaten by elephants (Alexandre 1978, Short 1981) and it is also dispersed by bats, hornbills and rodents (Taylor 1960). This species was common throughout the forest zone, especially in secondary forest $(\mathrm{S} 1,3)$ and it was especially common along particular hauling roadsides in Bia South being often observed in elephant dung as seedlings (S2). Ricinodendron heudelotii was not included in S4 since the sample areas were not heavily disturbed. In conclusion, this species is dispersed by elephants but is not obviously dependent on them and is able to thrive without them. It almost certainly benefits from canopy disruption by elephants however.

\section{Pentadesma butyracea Sabine (Guttiferae)}

The large, oil-rich seeds are liked by rodents. Taylor (1960) supposed that, in spite of heavy predation, some rodent dispersal might also occur. Alexandre (1978) and White et al. (1993) found seeds in dung and like Voorhoeve (1965) noted that elephants liked to strip bark of this species. This species is abundant in wet forests (especially Ghanaian Wet Evergreen forest), even as saplings and in areas without elephants ( $\mathrm{S} 1)$, and is occasionally also found on river banks of the dry forest zone (S3). The species is uncommon within drier forest zones such as Asukese and Bia South where it has not been found (in S1-S4 at least) as a seedling, and is rare as an adult (S2). In conclusion, this species is 
strongly restricted to wetter areas, with or without elephants, and hence is absent from many (drier) elephant areas.

Sacoglottis gabonensis (Baill.) Urb. (Humiriaceae)

The affinity of elephants for the fruits of this species is well-known, and elephants are known to travel far to find fruiting trees (Alexandre 1978, White 1994b). In Ghana the species occurs only in evergreen forests, particularly the Wet Evergreen, even forests like Cape Three Points F.R. with no records of elephants $(\mathrm{S} 1,3)$. This species is however too localized and rare in Ghana for any elephant effect to be apparent, but it does at least occur in forests without elephants.

Irvingia gabonensis (Aubry Lecomte) Baill. (Irvingiaceae)

The mango-like fruit has a fibrous 'stone', dispersed by elephants (Alexandre 1978, Short 1981). Under some circumstances it is eaten, and therefore has probably been consciously dispersed, by humans (Harris 1996). The species was found throughout the forest zone $(\mathrm{S} 1,3)$. Peak regeneration levels (c. 300 stems $\mathrm{km}^{-2}$ in sizes $\left.5-30 \mathrm{~cm} \mathrm{DBH}\right)$ occur in both elephant areas like Bia South G.P.R. and over vast non-elephant areas (S1). The occurrence of the species was insignificant in seedling plots in elephant areas of S2. Irvingia gabonensis is capable of regeneration and local dispersal without elephants but may have established its existing range with their help.

\section{Klainedoxa gabonensis Pierre ex Engl. (Irvingiaceae)}

The hard drupe with five woody pyrenes is dispersed by elephants (Alexandre 1978, Short 1981). Under some circumstances it is eaten, and therefore has probably been consciously dispersed, by humans (Harris 1996). Apparently viable fruits are often found buried in soil around the base of the tree (D. Harris, pers. comm.). The species was found to be common except in the drier forests $(\mathrm{S} 1,3)$. Regeneration $(5-30 \mathrm{~cm} \mathrm{dbh})$ is especially common in the Evergreen forests. However, there is a rather anomalous abundance in the (rather dry) Moist Semi-deciduous northwest subtype forests, such as Bia North and Subim Forest Reserves, with their elephant populations (S1). In elephantinhabited forests the species was not common in seedling plots (S2). In conclusion, this species can regenerate without elephants, but is probably promoted by them, especially towards the drier parts of its range.

\section{Mildbraediodendron excelsum Harms (Leguminosae)}

This is an exceptionally rare tree within Ghana, found (as a herbarium specimen) for certain only once, on Bosumkese Hill near Sunyani (its native status is therefore open to question). The distribution extends from Ghana to Zaïre, Sudan and Uganda (Lock 1989). (Keay (1989) remarks that the presence even in Nigeria is subject to confirmation.) In Uganda and Sudan it is known 
to be dispersed by elephants and other mammals. Although elephants are not found around Sunyani today, it used to be a centre in Ghana for the elephant trade (Sunyani is based on the Akan word Esono, an elephant). Two sterile specimens from S1 may be of this species, also from the Sunyani area. One of these specimens was of a seedling from a non-elephant area. Although this species may be rare because of lack of elephants, it is more likely to be rare for some other reason, because plants of all ages are extremely rare, even in elephant inhabited areas.

Swartzia fistuloides Harms (Leguminosae)

The fruit is a multi-grained pulse. This species is very rare in Upper Guinea (in Ghana and Côte d'Ivoire), and seems to have its extreme western limit in eastern Côte d'Ivoire (Aubréville 1959), but is nearly confined to Central Africa. Fruits are eaten by elephants (Short (1981) for Ghana; White et al. (1993) for Gabon). It has been collected in Ghana only once as a herbarium specimen from Fum Headwaters F.R. (where there are no records of elephants), and is not known in any current elephant area (S1,3). Short (1981) claims to have found seeds of this species in a dungpile during the early dry season while no regeneration of this species was found in the same forest during S2, giving an idea of how rare the species might be in Ghana. Like Mildbraediodendron excelsum this species might be rare for reasons other than the lack of elephants.

Strychnos spp. (Loganiaceae)

Of all the non-tree species, probably the most likely species to depend on elephants for regeneration are certain Strychnos spp., with their cannon-ball like or smaller fruits with wooden exocarps, which Alexandre (1978) and Martin (1989) reported as being dispersed by elephants (e.g. Strychnos aculeata: Hall \& Swaine 1981). However, S3 (the only study with any Strychnos data) suggests that no Strychnos species are strongly associated with elephant areas, and seedlings of $S$. aculeata were observed commonly in non-elephant forests (especially in swampy areas). It is likely that this type of fruit is well-dispersed along rivers, even if the adults are not restricted to such areas. In conclusion, elephants may help with dispersal away from rivers, but are not essential to regeneration. Broad-scale dispersal of Strychnos spp. may have been promoted by elephants in the past.

\section{Treculia africana Decne (Moraceae)}

A tree with an immense, many-seeded yellow fruit, spongy in texture, sometimes weighing over $10 \mathrm{~kg}$ (De Koning 1983) eaten by elephants (Short 1981). Taylor (1960) noted that many small animals eat the fallen fruits. This species is widespread $(\mathrm{S} 1,2)$ and found regenerating in areas both with and without elephants (S4). Conspicuous seed germination of complete fruit was observed 
under a parent tree in Bura FR where there are no elephants (S4). In conclusion, the germination does not depend absolutely on any animal. Animal dispersal of fruits probably benefits the species, but no specific benefit of elephants can be deduced from the data.

Panda oleosa Pierre (Pandaceae)

The fruit is a globose greenish-yellow drupe with a hard, pitted endocarp containing three seeds (Taylor 1960), eaten by elephants (Alexandre 1978, Guillaumet 1967, Short 1981, White et al. 1993). Panda oleosa is an understorey tree and found in smaller size classes throughout the country (S1, S3). The 5$30 \mathrm{~cm}$ DBH size class is well-represented in many forests $(\mathrm{S} 1)$ without elephants. However, this may well be a slow-growing tree, so we have no idea of how old various trees in this size class might be. In S4, it was more common (11 observations against two) in the sizes $20-60 \mathrm{~cm} \mathrm{DBH}$ in forests with elephants, but about equally as common (five:four) in the $1-\mathrm{m}$ height to $20-\mathrm{cm}$ DBH size class. Regeneration was seen occasionally in elephant dung on old roads in Bia (W. Hawthorne, pers. obs.), but was rare in the S2 plots. In one forest with no elephants (Nkrabia F.R.) many small seedlings were found around a parent tree (Ntim Gyakari, Ghana Forestry Dept., pers. comm.), although seedlings are generally not common in any forest (S3). Panda seedlings clearly occur in areas without elephants. In conclusion, the species can regenerate without elephants, but may have in the past been dispersed mostly by elephants.

Nauclea diderrichii (De Wild. \& Th. Dur.) Merrill (Rubiaceae)

A large timber tree regenerating only in gaps, with compound, fleshy orangecoloured fruits and very small seeds. Taylor (1960) and Voorhoeve (1965) state that the seeds are dispersed by small mammals, but mainly by birds. White et al. (1993) found seeds in dung and noted scar tissue on the trunk of this species. The species is not abundant generally, but found throughout the forest zone. Regeneration is mainly confined to disturbed areas $(\mathrm{S} 1,3)$. This is confirmed for Bia where better regeneration was noted along roads than in undisturbed forest or along skidding trails. It was thought likely that elephant movement along roads would have contributed to this pattern (S2). In the undisturbed forests of S4, a few saplings were recorded in both elephant and non-elephant areas. In conclusion, this species does not depend on elephants, but probably benefits slightly through dispersal by them, and even more significantly by their disruption of the canopy (as Ricinodendron).

Pancovia turbinata Radlk. (Sapindaceae)

This species germinates in elephant dung (Alexandre 1978) and is common throughout the Evergreen and Moist Semi-deciduous (southeast subtype) zones. The similar shrub $P$. sessiliftora is common throughout drier forests. There is no sign of elephant dependence in any of the studies (S1-S3). 
Chrysophyllum albidum G.Don., C. giganteum A.Chev. and C. subnudum Bak.

(Sapotaceae)

Seedlings of these three species are hard to tell apart. The sweet, fleshy fruits are enjoyed by many mammals, including humans who distribute and even cultivate them sometimes (especially C. albidum) (Hall \& Swaine 1981). It is unlikely that elephants have a strong preference for the sweet, fleshy fruits of one species over the other, as they are similar. The species are common and regenerating throughout the country, but slightly more so in western Ghana where elephants (and perhaps certain primates) are now most abundant ( $\mathrm{S}$, 3). This is confirmed by S4 where Chrysophyllum spp. were found in all four forests, but were significantly more common in elephant reserves. This also applies for Asukese and Bia, both elephant areas, where seedlings are found to be common, even in undisturbed forest in Bia (S2). In Bia G.P.R. C. giganteum is more typical of samples in the south of the forest (Hawthorne 1993), and this might influence the seasonal migrations of elephants discussed by Short (1983). In conclusion, this species does not depend on elephants, but probably benefits slightly through dispersal by them.

Omphalocarpum ahia A.Chev. (and other Omphalocarpum spp.) (Sapotaceae)

The cauliflorous fruits are large and almost spherical with about 10-30 seeds in a dark-coloured pulp. In Gabon, White et al. (1993) found fruits of the related species Omphalocarpum procerum in elephant dung. O. ahia is found scattered in swamps throughout the forest zone $(\mathrm{S} 1,3)$. Young regeneration was better in elephant reserves (eight records against one), while mature trees were also recorded on higher catena positions in some elephant-inhabited forests (S4). In conclusion, it is a species which quite probably benefits from elephants in the swamps to which it is mostly confined, especially through dispersal from one river system to another, but $O$. ahia is capable of regenerating without elephants. For dispersal to higher catena positions elephant dispersal might be important, as with the Strychnos spp. mentioned above.

Tieghemella heckelii Pierre ex Chev. (Sapotaceae)

It has been supposed that Tieghemella would disappear from Ghanaian forest without elephants (see Introduction). Tieghemella does not have a hard 'stone' like Panda, but has very oil-rich, large seeds of similar type to Pentadesma, eaten by elephants (Alexandre 1978, Guillaumet 1967, Short 1981, Voorhoeve 1965). The pulp is eaten by small animals, particularly rodents, as well as the oily cotyledons in the young seedlings (Taylor 1960), so the natural regeneration faces many problems. In Gabon, White et al. (1993) found fruits of the closely related species Tieghemella africana in elephant dung. Large and small trees are indeed common in elephant-inhabited areas, but they are not restricted to them. The species regenerates well in, for instance, Ebi Shelterbelt and several other reserves where there are no records or indications of elephant presence in recent years ( $\mathrm{S} 1,3$ and 4$)$. The absence of small regeneration in a forest 
rich in adults was remarked on for elephant-rich Bia South (Hawthorne 1993). It was not found as a seedling in the drier, Asukese (elephant) forest reserve either (S2). In general it was absent only from drier forests (S3). In conclusion, the species strongly favours wetter forests. It does not appear to depend on elephants for regeneration, and can thrive locally without them. Regeneration often seems to be a 'problem' (from a forestry point of view) even where elephants are common.

Desplatsia chrysochlamys (Mildb.\& Burret) Mildb. \& Burret, D. dewevrei (De Wild. \& Th. Dur.) Burret, D. subericarpa Bocq. (Tiliaceae)

The three small-tree species of this genus in Ghana are not easily distinguished as young seedlings, some or all of which are common in elephant dung (Hall \& Swaine 1981, Short 1981), and their fruits are similar, so they are likely to be affected similarly by elephants. Fruits are many seeded drupes resembling (very fibrous) peaches (De Koning 1983). The Akan name esonowisamfie means elephant's chewing sponge. The species are found throughout the country (S1). D. chrysochlamys is more abundant in the wettest areas; $D$. subericarpa in the driest, but there is a great deal of overlap, and regeneration of none of them appears to be restricted to elephant areas $(S 3,4)$. They were very common as regeneration in Bia and Asukese, especially in more open areas. In Bia they were often seen in elephant dung (S2). In conclusion, although clearly relished and dispersed by elephants, all available evidence suggests that the regeneration is not dependent on them.

Duboscia viridiflora (K.Schum.) Mildbr. (Tiliaceae)

A fluted tree with small ribbed fruits enjoyed by elephants in Liberia (Sachtler 1968), but scattered in Ghana, and nowhere very abundant. The fruits are fibrous and woody, resembling those of Desplatsia spp. S1 reveals greatest regeneration in Tinte Bepo F.R. (no elephants) but even here only eight trees of $5-30 \mathrm{~cm}$ dbh were recorded. D. viridiflora was recorded only twice in S3. In conclusion, the rather scanty data do not support a hypothesis of dependence on elephants, although $D$. viridiflora may benefit slightly from their presence.

Balanites wilsoniana Dawe \& Sprague (Zygophyllaceae)

A spiny, fluted, dry forest tree found from Côte d'Ivoire to Kenya (Aubréville 1959). The fruits contain one oil-rich seed (Aubréville 1959) and the oily cotyledons in the young seedlings are eaten by rodents, like those of Tieghemella (Taylor 1960). Fruits are regularly found in elephant dung-piles (Short 1981). Chapman et al. (1992) note seeds of this species germinate very much more successfully after passage through an elephant's gut. After 6 mo 50.9\% of the digested seeds $(n=232)$ had germinated opposed to $0.7 \%$ of seeds $(n=457)$ collected under mother trees. Beneficial effects of elephant dung-piles were remarked on by Buss (1990): 'seeds of the forest date (Balanites wilsoniana), 
which were often found in elephant droppings, were observed to germinate and grow to heights of $61 \mathrm{~cm}$ in 2 months'. An elephant-established trail network connecting all mature trees of this species was noticed during the fruiting season in Kibale F.R., Uganda (Buss 1990). Balanites wilsoniana is mainly recorded (in small or large sizes) in or close to current elephant areas in Ghana (S1-4). A single, unusual record of a mature tree near Accra (survivor from a time when elephants occurred there?) was made (S3). In Tain Tributaries II F.R. in the dry north of the forest zone near Sunyani (see Figure 1) large individuals occur, but seedlings have not been seen by the authors (S1). Peak regeneration occurs in the Asukese to Krokosua hills forests, where elephants occur (S1, S2). The species appears to be unsuited to the evergreen forests, although scattered, old individuals have been recorded in Atewa Range (Upland Evergreen) and Boin River F.R.s (Moist Evergreen) (S1). The data support a hypothesis of reliance on elephants for successful regeneration, and probably dispersal as well. Scattered records in areas well away from elephant ranges might indicate a history of elephants in these areas, particularly as smaller sizes are not well represented. However, presence of smaller trees in areas like Sui and Suhuma F.R.s suggest that either elephants have occurred in such areas in recent history, or the tree is capable of regenerating without elephants. Piles of seeds have also been seen germinating in dry forests (Opro River F.R.) where no elephants have been recorded for decades (W. Hawthorne, pers. obs.).

\section{DISGUSSION}

If a Ghanaian forest species is completely dependent on elephants for regeneration, then it is highly unlikely to be a species not mentioned by the workers in Taï and Bia, and in this paper. Species of this type would be expected to be much more abundant in or restricted, at least as seedlings, to elephantinhabited areas, and the vegetation of these elephant areas is well known. We have searched mostly in vain for good evidence to support a hypothesis of a decline in a plant population, particularly in terms of a failure of regeneration, following local elephant extinction. The number of species depending absolutely (or even almost exclusively) on elephants for regeneration may be as low, in Ghana, as two (Balanites and Panda), and even these can regenerate occasionally in their absence. All other species, including Tieghemella are apparently able to germinate (if not always rapidly) without passage through an elephant gut, and show no close dependence on elephants for germination. Even species with fruits as apparently specialized as Desplatsia spp. are regenerating abundantly without elephant assistance. We note that many elephantdispersed species are also known to be dispersed by other large mammals, including humans.

Having ruled out the possibility that many species are exclusively dependent on elephants for regeneration, we can consider the extent to which elephants 
contribute to the long-term survival of the plant species through their role as dispersers. Any effect of disappearance of dispersers is not likely to be noticed for many centuries, even in the seedling population, because adults are already in place, and well-dispersed. Populations may decline locally in the coming millennium as a consequence of local elephant extinction, but on this time scale the threat due to loss of elephant populations is rendered insignificant by the towering threat posed by climate or human population change, overexploitation, fire, and the current state of fragmentation of the forest.

A long-term (millennial) future in the forest mosaic almost certainly rests on the mobility of species within it, even if species can germinate locally. Elephants, in other words, operate at the broad scale of plant and forest regeneration-at finer scales, most plants can do without them. Even on this broad scale, other large mammals, such as duikers and humans, also contribute to the dispersal of many species favoured by elephants, probably including most of those species discussed above (L. White, pers. comm.). Considering their affinity for disturbed vegetation and promotion of plant dispersal, elephants are likely to have been very important in the establishment of Ghana's forests after the disruptions of long-term climatic changes (e.g. Maley 1996). Today, the benefits for local dispersal of those established populations are likely to be more marginal. Any effects are rendered insignificant-either counteracted or overshadowed-by concurrent changes in the forest due mainly to human activity.

Elephants are, of course, of extreme conservation concern and interest in their own right: we have already noted the small, isolated populations in West Africa. Natural resource managers should address this issue urgently, particularly by trying to create corridors, for instance to allow the migration from Bossematié forest, Côte d'Ivoire to Bia South, Ghana and surrounding areas (Parren \& De Graaf 1995). Species which exercise a special attraction to elephants e.g. Tieghemella, Parinari, Sacoglottis, Balanites and Panda (Martin 1989, Sachtler 1968, White 1994b) may be important to elephants: mature trees (especially Tieghemella) should be protected by forest managers for the sake of the elephants, not vice versa.

How important are elephants today to Ghanaian forests?

Elephants clearly provide some advantage to the many plant species which they disperse, and a very great advantage to one or two species like Balanites. The long-term demise of a few species, e.g. Panda oleosa, is anticipated without elephants even though these species do regenerate without them. It is notoriously difficult to prove a negative result, but we have found no hard evidence for any serious short-term decline of regeneration of elephant-dispersed trees, though we scanned extensive data on the subject.

Elephants certainly have a profound influence on forest structure-they tend to make gaps and keep forest open, by trampling and debarking (Buechner \& Dawkins 1961, Campbell 1991, Johnstone 1967, Kortlandt 1984, Laws et al. 
1975, Lock 1975, Sachtler 1968, Sheil 1996, Tchamba \& Seme 1993, Uganda Forestry Dept. 1957) but pioneer and other gap-loving species are far from threatened in forests, even undisturbed forests, without elephants. Human influences due to logging sometimes enhance elephant populations anyway (Struhsaker et al. 1996), even though species dispersed by elephants may have declined, due to increases in herbaceous plants following logging. Changes in elephant populations are followed by altered successional dynamics in some forests (e.g. Laws et al. 1975; Sheil 1996), and herein lies the most significant potential of loss of elephants on Upper Guinean forest. This is to a great extent compensated for in effect, if not in spirit, by greater human use of forests.

\section{ACKNOWLEDGEMENTS}

We thank the following for supporting the work which produced the data we discuss. The UK Department for International development (DFID, previously ODA) and Ghana Forestry Department supported the work of the Forest Resource Management Project. We are particularly grateful to the more than a hundred workers in the Ghanaian Forest Inventory and Management Project who have carried out some of the inventory work discussed above. The Ghana Game \& Wildlife Department helped with work in Ankasa G.P.R. and Bia National Park and G.P.R. The Lucie Burgers Foundation, The Netherlands supported S4. We thank also H.H.T. Prins and L. White as reviewers for their helpful comments.

\section{LITERATURE GITED}

ALEXANDRE, D. Y. 1977. Régéneration naturelle d'un arbre characteristique de la forêt équatorielle de Côte d'Ivoire: Turraeanthus africana Pellegr. Oecologia Plantarum 12:241-266.

ALEXANDRE, D. Y. 1978. Le rôle disseminateur des éléphants en forêt de Taï, Gôte d'Ivoire. La Terre et la Vie 32:47-72.

ALEXANDRE, D. Y. 1980. Caractère saisonnier de la fructification dans une forêt hygrophile de Côte d'Ivoire. La Terre et la Vie 34:335-350.

AUBRÉVILLE, A. 1959. La flore forestière de la Côte d'Ivoire. (Deuxième édition révisée.) Trois tomes. CTFT. Nogent-sur-Marne (Seine), France. 1031 pp.

BARNES, R. F. W. 1983. Effects of elephant browsing on woodlands in a Tanzanian National Park: measurements, models and management. Journal of Applied Ecology 20:531-540.

BARNES, R .F. W., BARNES, K. L., ALERS, M. P. T. \& BLOM, A. 1991. Man determines the distribution of elephants in the rain forests of north-eastern Gabon. African Journal of Ecology 29:54-63.

BARNES, R. F. W., AGNAGNA, M. \& ALERS, M. P. T. 1993. Elephants and ivory poaching in the forests of equatorial Africa: report of a field reconnaissance. Oryx 27:27-34.

BARNES, R. F. W, BLOM, A. \& ALERS, M. P. T. 1995. A review of the status of forest elephants Loxodonta africana in Central Africa. Biological Conservation 71:125-132.

BUEGHNER, H. K. \& DAWKINS, H. C. 1961. Vegetation change induced by elephants and fire in Murchison Falls National Park, Uganda. Ecology 42:752-766.

BUSS, I. O. 1961. Some observations on food habits and behaviour of the African elephant. Journal of Wildlife Management 25:131-148.

BUSS, I. O. 1990. Elephant life. Iowa State University Press, Ames. 191 pp.

CAMPBELL, D. G. 1991. Gap formation in tropical forest canopy by elephants, Oveng, Gabon, Central Africa. Biotropica 23:195-196.

CHAPMAN, L. J., CHAPMAN, C. A. \& WRANGHAM, R. W. 1992. Balanites wilsoniana: elephant dependent dispersal? Journal of Tropical Ecology 8:275-283. 
DICKINSON, B. 1990. Unpublished manuscript, 12 pp. Department of Game and Wildlife, Accra, Ghana. $12 \mathrm{pp}$.

DE LA MENSBRUGE, G. 1966. La germination et les plantules des essences arborées de la fôret dense humide de la Côte d'Ivoire. Centre Technique Forestier Tropical Publication no. 26, Nogent-sur-Marne (Seine), France. 382 pp.

DE KONING, J. 1983. La forêt du Banco. Tome I La forêt, tome II La flore. These doctoral, Mededelingen Landbouwhogeschool Wageningen 83-1. Wageningen, Pays-Bas, Université Agricole, Tome I: 156 pp., Tome II: $921 \mathrm{pp}$.

DUDLEY, J. P., MENSAH-NTIAMOAH, A. Y. \& KPELLE, D. G. 1992. Forest elephants in a rainforest fragment: preliminary findings from a wildlife conservation project in southern Ghana. African Journal of Ecology 30:116-126.

GUILLAUMET, J. L. 1967. Recherches sur la végétation et la flore de la région du Bas Cavally (Côte d'Ivoire). Mémoire ORSTOM No. 20. ORSTOM, Paris. 247 pp.

HALL, J. B. \& SWAINE, M. D. 1981. Distribution and ecology of vascular plants in a tropical rain forest. Forest vegetation in Ghana. Dr. W. Junk Publishers, The Hague, Netherlands. 383 pp.

HARRIS, D. J. 1996. A revision of the Irvingiaceae in Africa. Bulletin du Jardin Botanique National de Belgique 65:143-196.

HAWTHORNE, W. D. 1990. Field guide to the forest trees of Ghana. Natural Resources Institute, Chatham, UK. $278 \mathrm{pp}$

HAWTHORNE, W. D. 1993. Forest regeneration after logging in Bia South GPR, Ghana. O.D.A. Forestry Series 3, Natural Resources Institute, Chatham, UK. 52 pp.

HAWTHORNE, W. D. 1994. Fire and forest regeneration in Ghana. O.D.A.. Forestry Series 4. Natural Resources Institute, Chatham, UK. 53 pp.

HAWTHORNE, W. D. 1995a. Froggie (Forest Reserves of Ghana: Graphical Information Exhibitor). Programme/ database with manual for programme. (Published by IUCN to accompany Hawthorne \& Abu Juam, 1995.) $137 \mathrm{pp}$.

HAWTHORNE, W. D. 1995b. Ecological profiles of Ghanaian forest trees. Tropical Forestry Papers 29. Oxford Forestry Institute. Oxford, UK. 345 pp.

HAWTHORNE, W. D. 1996. Holes and the sums of parts in Ghanaian forest: regeneration, scale and sustainable use. Proceedings of the Roval Society Edinburgh 104B:75-176.

HAWTHORNE, W. D. \& ABU JUAM, M. 1995. Forest protection in Ghana (with particular reference to vegetation and plant species). IUCN, Gland, Switzerland and Cambridge, UK. 203 pp.

HOFT, R. \& HOFT, M. 1995. The differential effects of elephants on rain forest communities in the Shimba Hills, Kenya. Biological Conservation 73:67-79.

HOWE, H. F. 1993. Specialised and generalised dispersal systems: where does 'the paradigm' stand? Vegetatio 107/108:3-13.

JANZEN, D. H. 1970. Herbivores and the number of tree species in tropical forests. American Naturalist 104:501-528.

JOHNSTONE, R. C. B. 1967. Elephant protection problems in Budongo tropical high forest. Uganda Forestry Department Paper presented at 9th Commonwealth Forestry Conference, New Delhi, 1968. (Manuscript in Oxford Forestry Institute Library).

KEAY, R. W. J. 1989. Trees of Nigeria. Clarendon Press Oxford, UK. 476 pp.

KORTLANDT, A. 1984. Vegetation research and the 'bulldozer' herbivores of Africa. Pp. 205-226 in Chadwick, A. C. \& Sutton, S. L. (eds.). Tropical rain forest ecology and management. Blackwell Scientific Publications, Oxford, UK

LAWS, R. M., PARKER, I. S. C. \& JOHNSTONE, R. G. B. 1970. Elephants and their habitats in North Bunyoro, Uganda. East African Wildlife Journal 8:163-180.

LAWS, R. M., PARKER, I. S. G. \& JOHNSTONE, R. C. B. 1975. Elephants and their habitats: the ecology of elephants of North Bunyoro, Uganda. Clarendon Press, Oxford, UK. 376 pp.

LIEBERMAN, D., LIEBERMAN, M. \& MARTIN, G. 1987. Notes on seeds in elephant dung from Bia National Park, Ghana. Biotropica 19:365-369.

LEUTHOLD, W. 1977. Changes in tree populations in Tsavo East National Park, Kenya. East African Wildlife Journal 15:19-39.

LOCK, J. M. 1975. Preliminary results from fire and elephant exclusion plots in Kabalega National Park, Uganda. East African Wildlife Journal 15:229-232.

LOCK, J. M. 1989. Legumes of Africa: a checklist. Royal Botanic Gardens. Kew, UK. 619 pp.

MACK, A. L. 1993. The sizes of vertebrate-dispersed fruits: a neotropical-paleotropical comparison. American Naturalist 142:840-856.

MALEY, J. 1996. The African rain forest: main characteristics of changes in vegetation and climate from the Upper Cretaceous to the Quaternary. Proceedings of the Royal Society of Edinburgh 104B:31-73.

MARTIN, G. 1982. Management plan for the Bia Wildlife Conservation Areas, part I. Final report IUCN/WWF project 1251. Wildlife and National Parks Division, Ghana Forestry Commission, Accra, Ghana. $152 \mathrm{pp}$. 
MARTIN, G. 1989. Die Regenwälder Westafrikas. Oekologie, Bedrohung und Schutz. Birkhäuser, Basel, Switzerland. 235 pp.

MERZ, G. 1981. Recherches sur la biologie de nutrition et les habitats préférés de l'éléphant de forêt, Loxodonta africana cyclotis, Matschie 1900. Mammalia 45:299-312.

MERZ, G. 1986a. The status of the forest elephant Loxodonta africana cyclotis, Matschie, 1900, in the Gola Forest Reserves, Sierra Leone. Biological Conservation 36:83-94.

MERZ, G. 1986b. Counting elephants (Loxodonta africana cyclotis) in tropical rain forest with particular reference to the Taï National Park, Ivory Coast. African Journal of Ecology 24:61-68.

MERZ, G. 1986c. Movement patterns and group size of the African forest elephant Loxodonta africana cyclotis in the Taï National Park, Ivory Coast. African Journal of Ecology 24:133-136.

PARREN, M. P. E. 1991. Forest elephant (Loxodonta african cyclotis Matschie) messenger-boy or bulldozer? The possible impact on the vegetation, with special reference to 41 tree species of Ghana. MSc thesis, Department of Forestry, Agricultural University, Wageningen, The Netherlands. 38 pp.

PARREN, M. P. E. \& DE GRAAF, N. R. 1995. The quest for natural forest management in Ghana, Côte d'Ivoire and Liberia. Tropenbos Series 13. Tropenbos Foundation, Wageningen, The Netherlands. 199 pp.

PRINS, H. H. T. \& REITSMA, J.M. 1989. Mammalian biomass in an African equatorial rain forest. Journal of Animal Ecology 58:851-861.

ROTH, I. 1987. Stratification of a tropical forest as seen in dispersal types. Tasks for Vegetation Science 17. Dr. W. Junk Publishers, Dordrecht, The Netherlands. 324 pp.

SACHTLER, M. 1968. General report on national forest inventory in Liberia. Technical report 1. German Forestry Mission; Bureau of Forest and Wildlife Conservation, Department of Agriculture, Monrovia, Liberia. $148 \mathrm{pp}$.

SHEIL, D. 1996. The ecology of long term change in a Ugandan rain forest. PhD thesis, Department of Plant Sciences, University of Oxford, UK. 229 pp.

SHORT, J. 1981. Diet and feeding behaviour of the forest elephant. Mammalia 45:178-185.

SHORT, J. 1983. Density and seasonal movements of forest elephant (Loxodonta africana cyclotis, Matschie) in Bia National Park, Ghana. African Journal of Ecology 21:175-184.

SMART, N. O. E., HATTON, J. G. \& SPRUCE, D. H. N. 1985. The effect of long term exclusion of large herbivores on vegetation of Murchison Falls National Park, Uganda. Biological Conservation 33:229-245.

SPINAGE, C. A. \& GUINESS, F. E. 1971. Tree survival in the absence of elephants in the Akagera National Park, Rwanda. Journal of Applied Ecology 8:723-728.

STRUHSAKER, T. T., LWANGA, J. S. \& KASENENE, J. M. 1996. Elephants, selective logging and forest regeneration in the Kibale forest, Uganda. Journal of Tropical Ecology 12:45-64.

SWAINE, M. D. \& HALL, J. B. 1986. Forest structure and dynamics. Pp. 47-93 in G. W. Lawson (ed.). Plant ecology in West Africa. Systems and processes. J. Wiley \& Sons, Chichester, UK.

TAYLOR, C. J. 1960. Synecology and sylviculture in Ghana. T. Nelson \& Sons, Edinburgh, UK. 418 pp.

TCHAMBA, M. N. \& SEME, P. M. 1993. Diet and feeding behaviour of the forest elephant in the Santchou Reserve, Cameroon. African Journal of Ecology 31:165-171.

TERBORGH, J. 1990. Seed and fruit dispersal-commentary. Pp. 181-190 in Bawa, K. S. \& Hadley, M. (eds). Reproductive ecology of tropical forest plants. Man and the Biosphere Series 7. UNESCO, Parthenon Publishing Group, Paris and Carnforth, UK.

TUTIN, G. E. G., PARNELL, R. J. \& WHITE, F. 1996. Protecting seeds from primates: examples from Diospyros spp. in the Lopé Reserve, Gabon. Journal of Tropical Ecology 12:371-384.

UGANDA FORESTRY DEPARTMENT. 1957. Elephant damage. Unpublished Report of the Forestry Dept., Uganda. 9 pp.

VOORHOEVE, A. G. 1965. Liberian high forest trees. A systematical botanical study of the 75 most important or frequent high forest trees, with reference to numerous related species. PUDOC, Wageningen, The Netherlands. 416 pp.

WAITKUWAIT, W. E. 1992. Restauration d'un écosystème forestier: contribution de l'aménagement de la faune. Pp. 203-214 in Vooren, A. P., Schork, W., Blokhuis, W. A. \& Spijkerman, A. J.C. (eds). Compte rendu séminaire sur l'aménagement intégré des forêts denses humides et des zones agricoles périphériques. Tropenbos Series 1. Wageningen, Pays-Bas, La Fondation Tropenbos.

WHITE, F. 1976. The taxonomy, ecology and chorology of African Chrysobalanaceae (excluding Acioa). Bulletin du Jardin Botanique National de Belgique 46:265-350.

WHITE, F. 1983. The vegetation of Africa: a descriptive memoir to accompany the UNESCO/AETFAT/UNSO vegetation map of Africa. UNESCO, Paris. 384 pp.

WHITE, L. J. T. 1994a. Biomass of rain forest mammals in the Lopé reserve, Gabon. Journal of Animal Ecology 63:499-512.

WHITE, L. J. T. 1994b. Sacoglottis gabonensis fruiting and the seasonal movements of elephants in the Lopé reserve, Gabon. Journal of Tropical Ecology 10:121-125. 
WHITE, L. J. T., TUTIN, G. E. G. \& FERNANDEZ, M. 1993. Group composition and diet of forest elephants, Loxodonta africana cyclotis Matschie 1900, in the Lopé Reserve, Gabon. African Journal of Ecology 31:181-199.

WING, L. D. \& BUSS, I. O. 1970. Elephants and forests. Wildlife Monographs 19. 92 pp.

WONG, J. L. G. (ed.) 1989. Ghana forest inventory project seminar proceedings, 29-30 March 1989. Unpublished report, Forestry Department, Accra, Ghana. 101 pp. 